総 説

\title{
樹液流計測法を用いた林分蒸散量の計測 一森林管理による蒸散量の変化を評価するために一
}

\author{
篠原慶規 ${ }^{* 1}$ ・鶴田健二 ${ }^{2} \cdot$ 久米朋 宣 $^{3} \cdot$ 大柣恭 ${ }^{4}$
}

\begin{abstract}
近年, 水源涵養が, 針葉樹人工林の間伐や広葉樹林化, 竹林の伐採といった森林管理の主要な目的の一つとして位置付けら れている。しかし，森林の水資源量を評価する上で必要な蒸発散量の計測例が不足しており，森林管理に伴う水資源量の変化 は十分には評価できていない。そこで本総説では, 蒸発散量の主要要素である蒸散量の計測を促進するために, 蒸散量計測法 の一つである樹液流計測法について，計測原理や計測時の注意点について取りまとめた。まず，森林管理に伴う蒸散量の変化 を把握する上での樹液流計測法の有効性を他の蒸散量計測法と比較することで示した。次に, 樹液流計測法を用いた場合の単 木蒸散量の算出方法, 単木蒸散量から林分蒸散量へのスケーリングアップの方法について既往の研究例を基に説明した。最後 に, 今後, どのような森林でより計測を行う必要があるかを論じるために, 国内で樹液流計測法を用いて計測された林分蒸散 量を取りまとめた。その結果, カラマツ人工林, 広葉樹林, 竹林では, データの蓄積がほとんど進んでいないこと, スギ・ヒ ノキ人工林では，林齢 60 年以上や 20 年以下のデー夕蓄積が望まれることが明らかとなった。 キーワード : 蒸発散, グラニエ法, ヒートパルス法, 森林管理, 間伐
\end{abstract}

\begin{abstract}
Yoshinori Shinohara, ${ }^{*, 1}$ Kenji Tsuruta, ${ }^{2}$ Tomonori Kume, ${ }^{3}$ Kyoichi Otsuki ${ }^{4}$ (2013) An Overview of Stand-scale Transpiration Measurements Using the Sap Flow Technique for Evaluating the Effects of Forest Management Practices on Transpiration. J Jpn For Soc 95: 321-331 Recently, securing water resources has become one of the major purposes of forest management in Japan; this is done by thinning in coniferous plantations, replacing coniferous plantations with broadleaved forests, and conducting clearing or thinning operations in bamboo forests to reduce water loss to evapotranspiration. However, the effects of forest management practices on water resources have not been fully clarified because of a lack of evapotranspiration data from Japanese forests. Transpiration is a primary component of evapotranspiration in forested areas. We presented an overview of transpiration measurements based on the sap flow technique, a typical method used for measuring transpiration, to contribute to the accumulation of transpiration data for Japanese forests. Firstly, we compared the sap flow technique with other transpiration measurement methods and showed the usefulness of the sap flow technique for examining the effect of forest management practices on transpiration. Secondly, we explained the scaling-up procedures needed to up-scale from measures of sap flux densities to individual tree-scale transpiration and from individual tree-scale transpiration to stand-scale transpiration. Finally, we summarized stand-scale transpiration measurements based on the sap flow techniques as used in Japan, and recommend the types of forests which should be measured to help land and water managers have an informed discussion related to modifying forest management with the goal of securing water resources by forest practices. Measurements of transpiration are needed from larch plantations, broadleaved forests, and bamboo forests in Japan. Transpiration data measured in Japanese cedar and Japanese cypress plantations at ages of more than 60 years and less than 20 years would also be useful for the discussion.
\end{abstract}

Key words: evapotranspiration, forest management, Granier method, heat-pulse method, thinning

\section{I. は じめに}

近年, 日本各地において, 十分に管理されていない針 葉樹人工林の増加（恩田 2008）や竹林の拡大（西川ら 2005 ；小林・多田 2010）が報告されており，それに伴う 森林の公益的機能の低下を危惧する声がある。そのため, 公益的機能を高めるための森林管理として, 針葉樹人工林 の間伐，針葉樹人工林の広葉樹林化，竹林の伐採などが推 進されている（丸山ら $2009 ;$ 南光ら $2010 ;$ 新山ら 2010)。 森林の公益的機能は数多く提唱されているが（日本学術会
議 2001)，水資源の確保が，このような森林管理の目的の 一つとなっている（今若・佐藤 2008）。例えば, 2011 年 3 月 31 日現在, 全国の森林の $48 \%$ を占める保安林の $76 \%$ は 水源涵養を目的としている（林野庁 2012）。

森林の水資源量の大小は, 水資源賦存量あるいは渴水時 の流出量を用いて議論される（小松 2010 ; Komatsu et al. 2010a ; 蔵治 2012)。水資源賦存量は水資源として理論上 人間が最大限利用可能な水量で, 年降水量から年蒸発散量 を差し引くことで算出される。渴水時の河川流量は, 一 義的には地質の影響を強く受けるが（志水 1980 ; 虫明ら

*連絡先著者 (Corresponding author) E-mail : shinohara@agr.kyushu-u.ac.jp

${ }^{1}$ 九州大学大学院農学研究院 $=$ 812-8581 福岡市東区箱崎 6-10-1 (Faculty of Agriculture, Kyushu University, 6-10-1 Hakozaki, Fukuoka 8128581, Japan)

2 京都大学大学院農学研究科 ₹ 606-8502 京都市左京区北白川追分町 (Graduate School of Agriculture, Kyoto University, Kitashirakawa Oiwakecho, Sakyo-ku, Kyoto 606-8502, Japan)

${ }^{3}$ 国立台灣大学森林環境資源学系 ７ 10617 台北市羅斯福路四段一號 (School of Forestry and Resource Conservation, National Taiwan University, 1, Sec. 4, Roosevelt Road, Taipei, 10617, Taiwan)

${ }^{4}$ 九州大学福岡演習林 ＝ 811-2415 福岡県糟屋郡攸栗町津波黒 394 (Kasuya Research Forest, Kyushu University, 394 Tsubakuro, Sasaguri, Kasuyagun, Fukuoka 811-2415, Japan)

(2013 年 3 月 20 日受付, 2013 年 9 月 5 日受理) 
1981 ; Katsuyama et al. 2008)，植生変化の影響も受けるこ とが知られている（芳賀ら 2002 ; 玉井ら 2008）。植生変化 に伴う渴水時の流出量の変化は, 蒸発散量の変化と密接に 関わっている(Farlay et al. 2005; 藏本ら 2010)。したがって, 森林管理に伴う蒸発散量の変化を知ることは，森林管理に 伴う水資源量の変化を評価する上で極めて重要である。こ れまで日本では，数多くの試験流域が設定され（蔵治・芝 野 2001), 流域水収支法を用いることで，森林の変化と蒸 発散量（あるいは, 流出量）の関係について調べられて きた。それにより，森林の伐採（真板・鈴木 2007，2008） や森林の衰退（玉井ら 2004），針葉樹林から広葉樹林一の 転換（Komatsu et al. 2007，2008） が蒸発散量に与える影 響についての研究例が蓄積されつつある。一方で，人工林 の間伐が蒸発散量に与える影響を調べた研究は, 山本・池 田（2005）, Dung et al. (2012）など少数にとどまっており, 竹林に扔ける流域水収支法の適用例は皆無である。

森林の蒸発散は, 蒸散, 遮断蒸発，林床面蒸発に主に分 類される。なお，ここでの蒸散には，上層木の蒸散と下層 木の蒸散の両方が含まれる。一部の疎な森林を除けば（例 えば, Iida et al. 2009 ; Xue et al. 2011)，上層木の蒸散と 遮断蒸発が主要な構成要素となる（Vertessy et al. 2001; Wilson et al. 2001 ; 小松ら, 2005 ; Shinohara et al. 2009)。 このうち, 遮断蒸発については, 国内に拈いてもデータの 蓄積が進んでおり，それらを相互比較することで，針葉樹 林では立木密度と遮断蒸発率（遮断蒸発量/降水量）に正 の関係があること（小松 2007; Komatsu et al. 2007; 篠原ら, 2010), 竹林の遮断蒸発率は他の森林タイプと比較して小 さいことが示されている (Onozawa et al. 2009 ; Komatsu et al. 2010b;Shinohara et al. 2013a)。一方, 蒸散については, 遮断蒸発と比較して計測例が少ないため，十分な相互比較 は行われていない（小松ら 2009）。

以上のことより，森林管理が水資源量に与える影響を評 価する上で, 蒸散量の計測デー夕を蓄積していくことは 必要不可欠である。そこで本総説では，日本において蒸 散量の計測を推進するために, 蒸散量計測法の一つであ る樹液流計測法について，従来の研究を基にして，その 計測方法やその注意点などについて述べる。ここで，樹 液流計測法を取り上げるのは，森林管理による蒸散量の 違いを把握するために，この方法が有効な手法になりう ると考えられるからである（II 章参照）。なお，これまで も樹液流計測に基づく蒸散量の推定方法を取りまとめた 総説は, 国内外問わずいくつか発表されている（例えば, Swanson 1994; Granier et al. 1996a ; Smith and Allen 1996 ; 田中 1996 ; Wullschleger et al. 1998 ; Čermák et al. 2004 ; Lu et al. 2004 ; Asbjornsen et al. 2011)。しかし，これらは 樹液流計測法の種類や原理の違いを整理したものが中心で あり，本総説のように，日本の森林管理による蒸散量の違 いを明らかにするという目的で樹液流計測法を取りまとめ たものは, 著者らの知る限り存在しない。II 章では, 蒸 発散量計測法の中で樹液流計測法の特徵（他の方法と比較
した利点や欠点）について述べる。III 章では，樹液流計 測法を用いた単木蒸散量の算出方法, IV 章では, 単木蒸 散量から林分蒸散量へのスケーリングアップの方法につい て述べる。 $\mathbf{V}$ 章では, これまでの日本における林分蒸散量 の計測例を紹介し, 今後どのような森林でより樹液流計測 法による林分蒸散量計測を推進する必要があるのかについ て論ずる。

\section{II. 樹液流計測法の特徵}

一般的に, 森林管理が蒸散量に与える影響は, 林分ス ケール以上の空間スケールで評価することが望ましい（小 松ら 2009)。また, 蒸散量は, 森林の違いだけでなく, 気 候の影響を強く受ける。そのため, 森林間で蒸散量の比較 を行う場合，モデルに計測值を適用することで算出され たパラメータがしばしば用いられる（Kelliher et al. 1995 ; Komatsu 2005 ; Matsumoto et al. 2008a ; Komatsu et al. 2012)。その際，高い時間分解能のデータが利用できれば, 適用可能なモデルが多くなる。

蒸発散量や蒸散量を算出する方法には, 必要とするデー 夕の時間スケールや空間スケールに合わせて, ポロメー夕 法, 微気象学的方法, 土壤水収支法, 流域水収支法, 樹液 流計測法などが存在する。それぞれの方法で一般的に適用 される時間スケールや空間スケールを図-1に示した。ポ ロメータ法は, 個葉レベルの蒸散量を計測する方法であり, 単木や林分スケールの蒸散量を算出するためには，スケー リングアップが必要となる。その際，光環境など，ガス交 換に関わる様々な要素の空間的ばらつきを実際に計測する ことは難しいため，多くの仮定を含んだモデルが用いられ るのが一般的である（例えば, Miyazawa et al. 2011）。流 域水収支法は，流域スケールのデータが得られる点は有効 であるが，得られるデー夕の時間分解能は月単位以上であ る。また, 蒸発散の 3 要素を分離することができないため, 蒸散量のみを抽出したい場合, 他の方法と組み合わせる必 要がある（小松・堀田 2005）。土壤水収支法は, 土壤水分 の空間的ばらつきや，土壤下層への浸透など，不確実性が 大きいため（Wilson et al. 2001）, 他の方法と組み合わせて 利用されるのが一般的である（Delzon and Loustau 2005 ; Oren et al. 1998)。そのため, 森林管理が蒸散量に与える 影響を評価する上で特に必要な時間・空間スケールを満た しているのは, 微気象学的方法, 樹液流計測法の二つであ る。微気象学的方法は, 蒸発散量を推定する上で, 近年最 も一般的な方法であるが, 水平一様な地表面での計測を想 定した方法であるため, 日本の森林のように複雑な地形に 位置しており，林分面積も小さい場所における計測には， 多くの理論的制約がある（熊谷 2007 ; 斎藤 2009）。また, 降水が計測機器（超音波温度風速計および $\mathrm{CO}_{2} / \mathrm{H}_{2} \mathrm{O}$ ガス 分析計）に付着することによる誤差もあり（Mizutani $e t$ al. 1997 ; Granier et al. 2000), 降水の多いわが国のような 地域では降水時抢よび降水後のデー夕の取り扱いが問題と なりやすい。一方で，樹液流計測法は，それぞれの木で蒸 


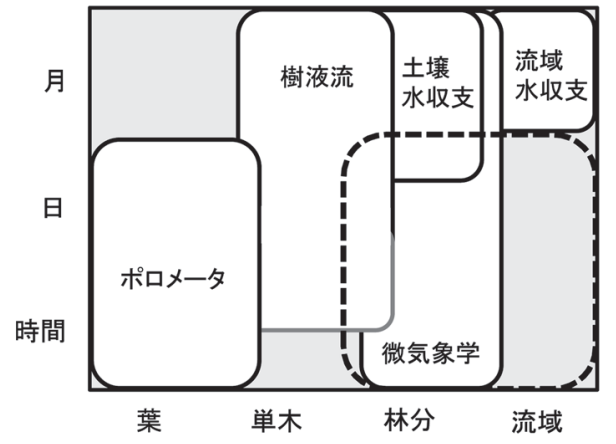

図-1. それぞれの蒸散量計測法の代表的な時空間的スケール 点線で示されているのが, 特にデータが求められる時空間的スケール。 樹液流計測法は, 時間単位でもしばしば用いられるが, デー夕の扱いに は注意が必要なため(本文参照)，一部，灰色線で示した。

散量を計測し，それをさらに林分スケールへ拡張していく 方法であり，地形や面積の条件に関して，理論的な制約は ない。国外では，実際に樹液流計測法を用いて，間伐や森 林成長による蒸散量の違いを調べる試みがいくつかなされ ている（Bréda et al. 1995 ; Roberts et al. 2001 ; Delzon and Loustau 2005 ; Simonin et al. 2007 ; Lagergren et al. 2008 ; Forrester et al. 2012)。国内でも，樹液流計測法によって, 間伐に伴う蒸散量の変化を評価した研究が一例存在する (Morikawa et al. 1986)。Morikawa et al.（1986）は，31 年 生のヒノキ林において，間伐により林分蒸散量が $21 \%$ 低 下したと報告している。以上のように，樹液流計測法は， 日本において，森林管理が蒸散量に与える影響を評価する 上で，有効な手段となりうると考えられる。

\section{III. 樹液流計測法を用いた単木蒸散量の算定}

樹木の幹は，樹皮，木部，髄に大別され，木部は，水を 流す辺材部と流さない心材部に分けられる。樹液流計測法 では，一般的に，胸高付近の辺材部にセンサーを挿入し， 樹液流速を計測する。樹液流は最終的に全て葉から放出さ れると仮定し, 胸高付近で計測された樹液流速に基づき, 樹冠で生じている蒸散量を算出する。ただし，胸高付近の 樹液流速と樹冠における蒸散との間には，樹体内の水の通 道抵抗および貯留に起因する 30 分〜2 時間程度の差がみ られる場合もあるので（Phillips et al. 1997 ; Čermák et al. 2007 ; Kumagai et al. 2009), 細かい時間ステップ（日単位 未満）で解析を行う場合は注意が必要である。

辺材と心材の区別は，針葉樹のように両者ではっきりと 色の区別がつく樹種に関しては，成長錐を用いて，コアサ ンプルを採取し，色の違いから求める。通常は，2 方向な いし 4 方向の辺材幅の平均值を用い，樹幹を円形と仮定す ることで辺材面積を算出する（鶴田ら 2011）。その際，例 えば，スギやヒノキでは，胸高直径に占める樹皮の割合は 5\%程度であるため（梶原 1973, 1985 ; 和口 2003）, 樹皮を 無視して推定した辺材面積は, 実際の辺材面積と比較して 最大 $10 \%$ 程度の誤差が含まれることが想定される（鶴田 ら 2011)。
辺材と心材の色の区別がつきにくい樹種では，(1) 実際 に樹液流速を測定し, 流速の有無で, 辺材と心材を判断す る (Jiménez et al. 2000)，（2）染色実験を行う（Meinzer et al. 2001 ; Gebauer et al. 2008 ; Tsuruta et al. 2010), （3）コアサンプルを採取し，含水率の違いから区別する (Flora and Cescatti 2006, 2008)，などの方法が用いられる。 なお，スギについては，通常は，コアサンプルを用いて色 の違いから判断するが，辺材と心材の間に，移行体であ る白線带が存在する（黒鳥 1954 ; Matsumura et al. 2005 ; Kuroda et al. 2009)。コアサンプルから辺材と白線帯の色 の違いを判断するのは難しい。そのため, Kumagai et al. （2005a）は，染色実験の結果などから，DBHによらず 1 $\mathrm{cm}$ と仮定しており, 後に続く研究でも同様の仮定がなさ れている (Kumagai et al. 2007, 2008)。

樹液流を測定する方法は，ヒーターの供給熱の収支を利 用した茎（幹）熱収支法とヒーターの供給熱の伝達状況 を利用した方法に主に分類される（Swanson 1994 ; 田中 1996)。前者は, 草本植物や直径の小さい木に対しては適 用性が検証されているが（Sakuratani 1984；作田ら 1992 ； Tanaka et al. 1993，1994), 幹が太くなると幹内部の温度 分布状況を把握することが困難になるため, 一般的には 直径の大きい木に適用することが困難である（Herzog et al. 1997)。一方, 後者の代表的な方法としてグラニエ法 （Granier 1987）とヒートパルス法（Closs 1958 ; Swanson and Whitfiled 1981）があり，ヒートパルス法は改良され た方法も存在する (Burgess et al. 2001)。グラニエ法とヒー トパルス法の計測原理の違いについては熊谷（2007）に詳 しく述べられている。目的に応じてグラニエ法, ヒートパ ルス法共によく用いられているが，ここではグラニエ法の 計測方法について主に紹介する。この理由は, 後述するよ うに, 林分スケールの蒸散量推定のためには数多くのセン サーが必要であるが，センサーが安価で自作可能なグラニ エ法は, ヒートパルス法と比較して, この点で有利である こと, ヒートパルス法で樹液流量を求めるためには, 個体 ごとに幹の含水率等を測定しヒートパルス速度を樹液流速 に換算する必要があるが (Swanson and Whitfield 1981), グラニエ法では所定の計測方法に従えば較正する必要がな いことによる。なお，グラニエ法に用いられるグラニエセ ンサーの自作法については, 熊谷朝臣氏のウェブページ （http://homepage1.nifty.com/kumabox/indexj.htm）で公 開されている。

グラニエ法では一般的に，ヒーター線と熱電対からなる ヒーターセンサーと, 熱電対からなるリファレンスセン サーの温度差を用いて, 以下の式より樹液流速 $u\left(\mathrm{~m}^{3} / \mathrm{m}^{2} \mathrm{~s}\right)$ を算出する。

$$
u=1.19 \times 10^{4}\left(\frac{\Delta T_{\max }-\Delta T(u)}{\Delta T(u)}\right)^{1.23}
$$

ここで, $\Delta T(u)$ はセンサー間の温度差 $\left({ }^{\circ} \mathrm{C}\right), \Delta T_{\max }$ は $u=0$ と仮定されるときの $\Delta T\left({ }^{\circ} \mathrm{C}\right)$ である。なお, 式(1) 中の係 数 $\left(1.19 \times 10^{4}, 1.23\right)$ は, 様々な種類の樹木の幹やおがく 
ずなどで作った人工的な幹などを用いて実験的に決定され たものであり（Granier 1985），樹種を問わず，この係数 が用いられている。一方で, 近年, 木部の特性などにより, 樹種ごとにこの係数が異なる可能性も指摘されているので (Wullschleger et al. 2011)，注意が必要である（V 章参照）。

グラニエ法で用いる標準的なセンサーの長さは $2 \mathrm{~cm} て ゙$ ある（熊谷 2007）。上記の係数は $2 \mathrm{~cm}$ で均質な流れであ ると仮定して算出している。そのため，辺材幅が $2 \mathrm{~cm}$ よ り小さい場合や，環孔材のように樹液流速が放射方向に極 端な偏った分布をしていると予想される場合 (Umebayashi et al. 2008; 佐藤ら 2010)，式(1）で算出した樹液流速は 誤差が大きくなると指摘されている（Bush et al. 2010）。 辺材幅が $2 \mathrm{~cm}$ より小さい場合に生じる誤差を補正する 式を Clearwater et al. (1999) が提案しており，樹液流 速の補正にしばしば用いられている（Herbst et al. 2007, 2008 ; Adelman et al. 2008 ; Kume et al. 2010b ; MacKay et al. 2012)。一方，樹液流速が放射方向に極端に偏った分布 をしている場合，長さを $1 \mathrm{~cm}$ に改良したセンサーが用い られることもある（Wang et al. 2010）。ただし，式(1）の 二つの係数は, 長さ $2 \mathrm{~cm}$ のセンサーを使って決定され たものであり， $1 \mathrm{~cm}$ のセンサーを用いた場合，係数が変 化する可能性が指摘されている（Lu et al. 2004）。そのた め, 実際の樹液流速とセンサーの出力值を比較すること で, 式(1）の係数を決め直している例もある（小野澤ら 2009 ; Kume et al. 2010a)。その他，樹幹内部も大きな樹 液流速が予想される場合には，センサーを徐々に移動させ ることで深い深度の樹液流速が計測可能な移動式センサー （Delzon et al. 2004 ; Tateishi et al. 2010）を用いる場合も ある。

単木当りの蒸散量は, 式(1) で求めた樹液流速を用いて 以下の式で示される（Granier 1985，1987）。

$$
Q=\bar{u} \times A_{S}
$$

ここで, $Q$ は単木蒸散量 $\left(\mathrm{m}^{3} / \mathrm{s}\right), \bar{u}$ は樹幹内の平均樹液 流速 $\left(\mathrm{m}^{3} / \mathrm{m}^{2} \mathrm{~s}\right), A_{S}$ は辺材面積 $\left(\mathrm{m}^{2}\right)$ である。樹幹内の 樹液流速は，環孔材のように極端に偏った分布をしていな い場合でも，樹幹内を均質に流れている訳ではなく，放 射方向のばらつきと周囲方向のばらつきが存在する（図2)。放射方向のばらつきは，樹木の木部構造の変化など に依存していると考えられており（Hirose et al. 2005），樹 幹内部ほど流速が遅くなる傾向にある（Oren et al. 1998 ; Kumagai et al. 2007 ; Ford et al. 2007 ; Kume et al.2012a)。 一方で，樹液流速のピークは最外部よりは少し内部にみら れるとする報告や（Lu et al. 2000 ; James et al. 2002 ; Ford et al. 2004 ; Gebauer et al. 2008)，内部でも外部と同程度 の流速が計測されている例もある（Phillips et al. 1996 ; Flora and Cescatti 2006)。

周囲方向のばらつきは, 導管径などの木部構造（Tateishi et al. 2008）や,樹冠上の太陽のあたり方のばらつき（Oren et al. 1999), 樹冠の葉の付き方（López-Bernal et al. 2010),

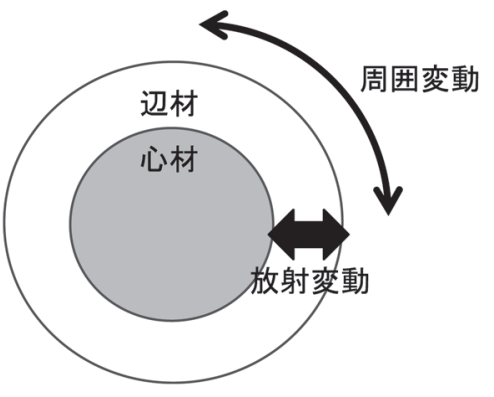

図-2. 樹幹断面における樹液流の放射方向のばらつきと周囲 方向のばらつきの模式図

土壤水分の空間的ばらつき（Lu et al. 2000）などによって 生じると考えられている。Vertessy et al. (1997) は, 樹幹 が円形に近い木は，そうでない木と比較して周囲方向のば らつきは小さいと報告している。このことから，樹幹が円 形に近いスギやヒノキでは, 周囲方向のばらつきが考慮さ れてこなかった (Kumagai et al. 2007, 2008; Kume et al. 2010b)。しかし, Tsuruta et al. (2010) は, 6 本のヒノキ で樹液流速の周囲変動を計測し，周囲変動を考慮しない場 合，単木蒸散量の推定に $20 \%$ 程度の誤差を含むと報告し ている。また，同程度の周囲変動は，他の樹種でも報告さ れている (Oren et al. 1999 ; Lu et al. 2000 ; Tateishi et al. 2008 ; Kume et al. 2012a)。

このような放射方向や周囲方向のばらつきを考虑するに は数多くのセンサーが必要となると共に, 設置やメンテナ ンスにも多大な労力が必要となる。そのため, 放射方向や 周囲方向のばらつきは短期間のみ計測し，あらかじめ連続 観測しているセンサーとの関係を得ておくことで, 計測さ れていない期間のスケーリングアップが行われる場合があ る（Tateishi et al. 2010）。ただし，樹液流速の放射方向や 周囲方向のばらつきは, 土壤水分量や飽差によって変化す るとの報告もあるため (Adelman et al. 2008 ; Loranty et al. 2008)，季節ごとに樹液流速と関連要素との関係を得るな ど工夫が必要である。

\section{IV. 林分蒸散量へのスケーリングアップ}

林分スケールで蒸散量を推定する場合，単木スケールと 違って，すべての木で辺材面積と樹液流速を計測すること は難しい。そのため，林分の直径階などに合わせて決めら れた一部の木のみで樹液流速と辺材面積が計測され，これ らのデータを用いてスケーリングアップが行われるのが一 般的である(熊谷 2007)。単木蒸散量から林分蒸散量への スケーリングアップには様々な方法が考案されているが, 主に武つの方法がよく用いられる。一つ目は単木蒸散量を 直接用いてスケーリングアップを行う方法で，林分蒸散量 は以下の式で表される（Čermák et al. 2004 ; Chang et al. 2006 ; Kume et al.2012a)。

$$
E=\sum Q / A_{G}
$$


表-1. 林分総辺材面積 $\left(A_{S}\right)$ と林分平均樹液流速 $\left(J_{S}\right)$ を算出するための必要サンプル数とそのサンプル数における変動係数

\begin{tabular}{|c|c|c|c|c|c|c|c|c|c|}
\hline \multirow{2}{*}{ 番号 } & \multirow{2}{*}{ 樹種 } & \multirow{2}{*}{$\begin{array}{c}\text { 立木密度 } \\
\text { (本/ha) }\end{array}$} & \multirow{2}{*}{$\begin{array}{c}\text { 平均 DBH } \\
(\mathrm{cm})\end{array}$} & \multirow[t]{2}{*}{ 計測本数 } & \multicolumn{2}{|c|}{ 必要サンプル数 } & \multicolumn{2}{|c|}{ 変動係数 (\%) } & \multirow{2}{*}{ References } \\
\hline & & & & & $A_{S}$ & $J_{S}$ & $A_{S}$ & $J_{S}$ & \\
\hline \multirow[t]{2}{*}{ \#4 } & スギ & 1159 & 32 & 14 & - & $>12$ & - & $3^{* 3, * 4}$ & Kumagai et al. (2005a) \\
\hline & スギ & 474 & 27.1 & 921 & 20 & - & $4^{* 4}$ & - & Kumagai et al. (2005b) \\
\hline \#5 & スギ & 1575 & 23.8 & 23 & - & 10 & - & 10 & Kumagai et al. (2007) \\
\hline$\# 6$ & スギ & 904 & 40.3 & 15 & - & 10 & - & 10 & Kumagai et al. (2007) \\
\hline \multirow[t]{2}{*}{$\# 13$} & ヒノキ & 1450 & 21 & 58 & 10 & 15 & 5.8 & 12.0 & Kume et al. (2010b) \\
\hline & ヒノキ & 820 & 25.8 & 1226 & 20 & - & $3^{* 4}$ & - & Kumagai et al. (2005b) \\
\hline \#18 & モウソウチク & 4000 & 11 & $40 * 1 / 16^{* 2}$ & 12 & 11 & 5.6 & 7.5 & Kume et al. (2010a) \\
\hline
\end{tabular}

ここで, $E$ は林分蒸散量 $(\mathrm{m} / \mathrm{s}), A_{G}$ は林分面積 $\left(\mathrm{m}^{2}\right)$ で ある。この式を用いた場合，まず，樹液流速を計測した供 試木のデー夕を用いて, 樹木特性と単木蒸散量の関係式を 作成する。そして，この式と対象林分内の各木の樹木特性 のデータを用いて，非計測木の単木蒸散量 $Q$ を推定する。 樹木特性としては, 葉面積や胸高断面積などが用いられて きたが (Hatton et al. 1995 ; Oren et al. 1998 ; Wullschleger et al. 1998), 近年は, 単木蒸散量と強い相関がみられ，か つ容易に計測可能な DBH を用いることが多い (Kume et al. 2012a)。

二つ目は, 辺材面積と樹液流速を別々にスケーリング アップする方法であり，林分蒸散量は以下の式で計算され る (Granier et al. 1996b ; Pataki and Oren 2003)

$$
E=J_{S} \frac{A_{S_{\text {stand }}}}{A_{G}}
$$

ここで, $J_{S}$ は林分平均樹液流速 $\left(\mathrm{m}^{3} / \mathrm{m}^{2} \mathrm{~s}\right), A_{S_{\text {s stand }}}$ は林 分総辺材面積 $\left(\mathrm{m}^{2}\right)$ である。この式を用いた場合，まず， 辺材面積を計測した木のデー夕を用いて，DBH から辺材 面積を推定するアロメトリー式を作成する。このアロメト リー式から非計測木の辺材面積を推定し，林分総辺材面積 $A_{S_{-} \text {stand }}$ を算出する。林分樹液流速については，放射方向の 変動を考慮し, 各深度の平均樹液流速を用いて算出される。 例えば，深さ $0 \sim 20 ， 20 \sim 40 ， 40 \sim 60 \mathrm{~mm}$ で計測が行われ た場合， $J_{S}$ は，以下の式を用いて算出される（Kumagai et al. 2005a, 2007)。

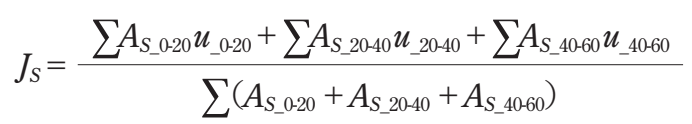

ここで, $A_{S_{-} 0-20}, A_{S_{-} 20-40}, A_{S_{-40-60}}$ はそれぞれの深度の総辺材 面積 $\left(\mathrm{m}^{2}\right), u_{0-20}, u_{-20-40}, u_{-40-60}$ はそれぞれの梁度の平均 樹液流速 $\left(\mathrm{m}^{3} / \mathrm{m}^{2} \mathrm{~s}\right)$ である。

林分スケール（もしくは, それ以上のスケール）の蒸散 量を推定する際, 樹液流速の樹幹内の変動と樹木間の変動 が誤差の要因となる。Kume et al. (2012a) は, 中国の黄土 高原のニセアカシア林（Robinia pseudoacacia）とリョウ トウナラ林 (Quercus liaotungensis) において, 他の研究 と同程度の放射方向，周囲方向の樹液流速の変動があるも
のの, これらが林分スケールの蒸散量推定に与える影響 は, 樹木間の樹液流速の変動と比べると小さいことを報告 している。また, Ford et al. (2007) は, アメリカのストロー ブマツ林 (Pinus strobus L.) において, 流域スケールの蒸 散量を推定する際，樹幹内の樹液流速の変動よりも，樹木 間の樹液流速の変動の方が重要であると述べている。この ように，樹木間の変動の方が，樹幹内の変動よりも，林分 スケールの蒸散量を推定する上で重要であると考えられて いる。また, 樹液流速と同様, 辺材面積にも個体間のば らつきがあり，これが林分総辺材面積の推定精度に影響を 与え, ひいては林分蒸散量の誤差要因となる (Kumagai et al. 2005b)。

表-1には，これまで日本において計算された， $A_{S_{\text {stand }}}$ と $J_{S}$ を算出するために必要なサンプル数を示した。これ らの必要サンプル数はモンテカルロ法を用いて計算されて いる。母集団のデー夕と乱数を用いて, それぞれの標本数 に対する確率密度関数を求め, 変動係数が十分に小さくな る標本数（これ以上標本数を大きくしても変動係数が減少 しない標本数）を必要サンプル数としている。この際, 林 分蒸散量は式(4)を用いて計算されている。これによると, 樹種や林分の特性（立木密度やDBH など）によって特に 大きな差はなく, $A_{S}$ で 10〜20 本， $J_{S}$ で 10〜15 本である ことがわかる。この本数は, 放射方向の変動も考慮した場 合の本数である。なお，これらは，すべて一斉林を対象と したものであり, 樹種や林分構造が複雑な森林を対象とし た場合は，これよりも大きくなる可能性もある。

近年では，流域スケール（もしくはそれ以上のスケー ル）の蒸散量推定に, 樹液流計測が適用可能であるか否か の検証が行われるようになってきた（Wilson et al. 2001； Ford et al. 2007 ; Kumagai et al., 2007; Mackay et al. 2010)。 Kumagai et al. (2007) や Ford et al. (2007) は, 単一の樹種 で覆われた流域において, 流域内の林分蒸散量 $E$ のばら つきを生み出す最大の要因はプロット間の林分総辺材面 積 $A_{S_{\text {stand }}}$ のばらつきであり, 林分平均樹液流速 $J_{S}$ は 1 プ ロットの計測で十分であると述べている。一方で，単一樹 種で覆われた流域においても, プロット間で林分平均樹液 流速 $J_{S}$ の大きなばらつきがみられる流域もある（Kume $e t$ $a l .2012 b) 。 今$ 後, 樹液流計測法を用いて, 流域スケール 
の蒸散量推定が数多く行われることで, 効率的な計測デザ インが提案されることが期待される。

\section{V. これまでの計測例と今後の課題}

\section{1. データ蓄積のプロセス}

森林管理が蒸散量に与える影響を評価する上で，著者ら は，まず蒸散量のデー夕蓄積を進めることが重要であると 考えている。その際，(1) 計測例の少ない樹種のデー夕を 蓄積する，（2）様々な林分構造（例えば，立木密度，胸高 断面積合計，林分平均樹高）を持つ林分でデータを蓄積す る，（3）間伐直後など，非定常状態のデー夕も蓄積する, の三つのプロセスで進めていくことが有効であると考えて いる。

まず，(1)では，これまで計測例のほとんどない樹種の データを蓄積し，他の樹種と比較することで，樹種ごとの 蒸散量の違いを大まかに把握することが可能になる。この ような比較を行う際，同一の気象条件で得られたデー夕同 士を比較することが望ましい。なぜなら，蒸散量は，樹種 や林分構造だけでなく, 気象条件の影響を強く受けるから である（小松ら 2005）。比較対象のデー夕が同一気象条件 で計測されていない場合は，モデルを使った比較が有効で ある。比較を行う森林のそれぞれで，気象デー夕（気温, 全天日射量, 飽差など) から蒸散量を推定できるモデル（気 象データと蒸散量との関係式）を構築する。そのモデルに 同一の気象データを入力することで計算される蒸散量を用 いることで, 気象条件の違いを排除して, 森林間で蒸散量 を比較することが可能となる。Komatsu et al. (2010b) は, このような方法を用いて，モウソウチク 1 林分の年蒸散量
（表-2の\#18：567 mm）が，同じ九州で計測された針葉樹 林よりも極めて大きいことを報告している（表-2 の \#5： $322 \mathrm{~mm}$, \#6 : $478 \mathrm{~mm}$, \#13:245 mm)。もし, それぞれ の森林の蒸散量が同一型のモデルで推定することができれ ば，構築されたモデル中のパラメー夕を比較することによ り，蒸散量の大小を判断することも可能である。

次に，(2）で，林分構造の異なる林分のデー夕を蓄積す ることで，(1) で行った樹種間の比較がより有効的に行え るようになる。さらに, 同一樹種において数多くのデータ が計測されれば，同一の気象条件を想定した場合の蒸散量 （もしくはモデルパラメータ）と林分構造の関係式を得る ことにより，任意の林分構造の蒸散量を推定することが可 能になる。例えば，蒸散量と立木密度や胸高断面積合計の 関係式を得ることで, 間伐による蒸散量の変化を立木密度 や胸高断面積合計の変化から定量的に評価することが可能 になる。また，林分収穫表などから得られる，それぞれの 林齢における林分構造のデータを用いることで, 森林成長 による蒸散量の変化を林分構造の変化から知ることが可能 になる。

最後に，（3）で，非定常状態でのデー夕を蓄積すること で，(2) で得られた結果が非定常状態でも有効かどうか確 かめることができる。

\section{2. 森林タイプ別の進渉状況}

これまで日本の森林（果樹を除く）で樹液流計測法に基 づいて, 林分スケールの蒸散量を計測した例を表-2に示 した。これをみると，森林タイプの違いによりデータの蓄 積量に大きな差がみられる。V.1. で示した三つのプロセス に従うとすれば，それぞれの森林タイプにおける進渉状況

表-2. 日本に抢ける樹液流計測を用いた林分蒸散量の算出例（方法の HP はヒートパルス法，Gはグラニエ法）

\begin{tabular}{|c|c|c|c|c|c|c|c|c|c|c|c|}
\hline 番号 & 樹種 & 場所, 県名 & プロット名 & 方法 & $\begin{array}{l}\text { 林齢 } \\
\text { (年) }\end{array}$ & $\begin{array}{l}\text { 立木密度 } \\
\text { (本/ha) }\end{array}$ & $\begin{array}{c}\text { 平均 DBH } \\
(\mathrm{cm})\end{array}$ & $\begin{array}{c}\text { 平均樹高 } \\
\text { (m) }\end{array}$ & $\begin{array}{l}\text { 計測本数 } \\
\text { (本) }\end{array}$ & $\begin{array}{c}\text { 計測期間 } \\
\text { (月） }\end{array}$ & Reference \\
\hline$\# 1$ & スギ & 清澄, 千葉 & 1 & $\mathrm{HP}$ & 19 & 5200 & $8.1^{* 1}$ & 6.6 & 6 & $11^{* 2}$ & 丹下 (1987) \\
\hline$\# 2$ & スギ & 清澄, 千葉 & 3 & HP & 19 & 4900 & $9^{* 1}$ & 0.1 & 6 & $11^{* 2}$ & 丹下（1987） \\
\hline$\# 3$ & スギ & 清澄, 千葉 & 5 & $\mathrm{HP}$ & 19 & 2500 & $11.6^{* 1}$ & 15 & 6 & $11^{* 2}$ & 丹下（1987） \\
\hline$\# 4$ & スギ & 椎葉, 宮崎 & & $\mathrm{G}$ & 32 & 1159 & 32 & 20 & 14 & $<1$ & Kumagai et al. (2005a) \\
\hline$\# 5$ & スギ & 鹿北, 熊本 & UP & G & 50 & 1575 & 23.8 & 22 & 23 & 18 & Kumagai et al. $(2007,2008)$ \\
\hline$\# 6$ & スギ & 鹿北, 熊本 & LP & G & 50 & 904 & 40.3 & 32 & 15 & 18 & Kumagai et al. $(2007,2008)$ \\
\hline$\# 7$ & スギ & 鹿北, 熊本 & $\mathrm{S}$ & G & 50 & 1330 & 26.6 & 24 & 19 & 13 & Komatsu et al. (2010b) \\
\hline$\# 8$ & スギ & 白山, 石川 & & G & 55 & 600 & 48.5 & 27.9 & 18 & $<1$ & Shinohara et al. (2013b) \\
\hline$\# 9$ & ヒノキ & 秩父，埼玉 & & HP & 42 & 1698 & 22.6 & & 11 & $<1$ & 森川（1974） \\
\hline$\# 10$ & ヒノキ & 加波山, 茨城 & 間伐前 & HP & 31 & 1750 & 18.2 & 13.5 & 6 & 5 & Morikawa et al. (1986) \\
\hline$\# 11$ & ヒノキ & 加波山, 茨城 & 間伐後 & HP & 32 & 1325 & 18.7 & 14.1 & 6 & 5 & Morikawa et al. (1986) \\
\hline$\# 12$ & ヒノキ & 御手洗水, 福岡 & & $\mathrm{G}$ & 47 & 1600 & 20.2 & 14.2 & 20 & 1 & 藤山ら（2005） \\
\hline \#13 & ヒノキ & 御手洗水, 福岡 & & G & 50 & 1450 & 15.6 & 15.6 & 60 & $>12$ & $\begin{array}{l}\text { Komatsu et al. (2010b), } \\
\text { Kume et al. (2010b) }\end{array}$ \\
\hline$\# 14$ & ヒノキ & 新建, 福岡 & Hiwada & G & 98 & 350 & 44.6 & 8 & 7 & $>12$ & 鶴田（2011） \\
\hline \#15 & ヒノキ & 新建, 福岡 & Sakuta & G & 18 & 2100 & 13.5 & 25 & 10 & $>12$ & 鶴田（2011） \\
\hline$\# 16$ & アカマツ & 筑波, 茨城 & & G & $50^{* 3}$ & $680^{* 3}$ & $18.4^{* 3}$ & $15.0^{* 3}$ & $4^{* 3}$ & 12 & Iida et al. (2006) \\
\hline$\# 17$ & ミズナラ & 川上, 長野 & & G & & 790 & 19.3 & 14 & 3 & 4 & 飯田ら（2006） \\
\hline \#18 & モウソウチク & カグヤ, 福岡 & & G & & 4000 & 11 & 15 & 16 & 13 & $\begin{array}{l}\text { Kume et al. }(2010 \mathrm{a}) \text {, } \\
\text { Komatsu et al. }(2010 \mathrm{~b})\end{array}$ \\
\hline
\end{tabular}

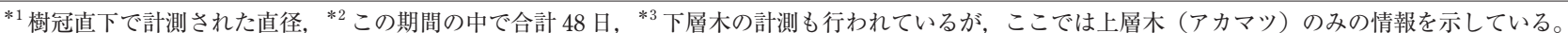


は以下の通りである。

\section{1）針葉樹林}

日本の主な針葉樹人工林の構成種は，スギ・ヒノキ・カ ラマッである。そのうち，スギ・ヒノキについては，計測 データが蓄積されつつある。しかし, 計測された森林の林 齢に偏りがあるため，これまであまり計測されていない林 齢 60 年以上や 20 年以下のデー夕を蓄積されることが特に 望まれる。それと共に，これまで Morikawa et al. (1986) 以外, 行われていない非定常状態での計測も進めていく必 要があると考えられる。

一方で，国内におけるカラマツ林での計測例は，筆者ら の知る限り存在しない。そのため, 北海道などカラマツが 人工林として選択される地域において, 森林管理が蒸散量 に与える影響を評価するためには，カラマツのデータ収集 の必要性が高いと考えられる。

\section{2) 広葉樹林}

広葉樹林の蒸散量のデー夕は, 広葉樹林から針葉樹林へ の転換（もしくは，その逆）や，竹林の広葉樹林への拡大 が蒸散量に与える影響を知る上で必要不可欠である。広葉 樹林では，単木スケールでの計測例はみられるものの（例 え ば, Kobayashi and Tanaka 2001; Kubota et al. 2005a, 2005b ; Tateishi et al. 2010), 林分スケール以上の蒸散量 を検討した例は飯田ら（2006）以外存在しない。そのため, 現時点では，樹液流計測に基づいて，広葉樹林と他の森林 タイプとの蒸散量の比較が十分には行えない状況にある （Komatsu et al.2010b）。そこで，まずは，広葉樹林におい ても林分蒸散量を計測し，針葉樹林や竹林の計測值と比較 することが求められる。

3) 竹林

竹林では，モウソウチク林における計測例が 1 例あるの みである。この研究から，モウソウチク林の蒸散量は，夏 季に特に大きく，年蒸散量は，同じ九州地方で計測された 針葉樹林と比較して，約 200〜300 mm 大きいことが報告 されている (Komatsu et al. 2010b)。今後は，異なる樹冠 構造を持つ竹林で計測を行うことで，この結果の一般性 を高めることが求められる。上記の計測は，立木密度が 約 4,000 本/ha の場所で行われたものである。一方で，近 年問題となっている放置竹林では立木密度が 10,000 本/ha 近くになる場所もある（豊田ら 2005 ；横尾ら 2005 ；小谷・ 江崎 2012)。そのため, 立木密度の大きい竹林で計測する ことが特に重要であると考えられる。

\section{3. 今後の課題と展望}

樹液流計測に基づいて蒸散量を比較するためには，上 記のようにデー夕を蓄積することのみならず，樹液流計 測の精度を向上させていくことも重要であると考えられ る。具体的には，(1）共通の係数を用いることによる誤差, （2）長期計測に関わる誤差，の 2 点について検証する必要 があると考えている。（1）に関して，近年，様々な樹種で, 樹液流速とセンサー間の温度差の関係（式(1)）を調べた ところ，Granier（1985）の係数が適用できない事例も報
告されている。例えば, Steppe et al. (2010) は, アメリカ ブナを用いて室内実験を行い，センサー間の温度差の計測 值と Granier（1985）の係数を用いて算出した樹液流速は, 実際の樹液流速を $60 \%$ 過小評価したと報告している。ま た, Wullschleger et al. (2011) は，モデルを用いて，樹幹 の熱伝導率の違いにより，センサー間の温度差と樹液流速 の関係は異なることを示している。これは, Granier (1985) の係数を用いた場合, 異なる樹種間で蒸散量の比較が十分 に行えない可能性を示唆するものである。日本の代表的な 樹種において，Granier（1985）の係数の適用性を確かめた 研究はほとんどないので，樹種間で蒸散量を比較する前に 予め調べられておくことが望まれる。（2）に関しては，樹 液流計測を用いて 1 成長期以上の長期計測を行った場合, 樹木の成長や組織の損傷などでセンサー付近の樹液流速が 低下することが指摘されている。 Moore et al. (2010) は, 土壤水分と飽差が同様の条件下に押いて, 計測開始後 2 年目の樹液流速は, 計測開始後 1 年目と比較して, $30 \sim$ 45\%低下したと報告している。そのため, 長期計測が行わ れる際は, 定期的にセンサーの入れ替えが行われている(例 えば, Ford et al. 2007)。今後, Moore et al. (2010) と同 様の研究が行われ，長期計測に関する指針が作られること が望まれる。

先にも述べた通り, 樹液流計測で算出されるのは, 蒸発 散の項目のうち, 上層木の蒸散量のみである。一方で, 強 度間伐などが行われた場合などで，上層木の葉面積が小さ くなると, 全蒸発散に占める下層木の蒸散量や林床面蒸発 量の割合が大きくなることが推察される（Iida et al. 2006 ; Daikoku et al. 2008)。それを補う方法として,小松ら (2009) は，樹液流計測法と土壤水収支法の併用を提案している。 また，日本では，微気象学的な方法での蒸発散量の計測例 も蓄積されている（Hirano et al. 2003 ; Kosugi et al. 2007 ; Matsumoto et al. 2008b)。これらの結果も合わせて利用す ることで，より効果的な評価が可能になると考えられる。

本研究の一部は独立行政法人科学技術振興機構の戦略的創造研究推 進事業 (CREST) における研究課題「荒廃人工林の管理による流量増加 と河川環境の改善を図る革新的な技術の開発」, 九州大学教育研究プロ グラム・研究拠点形成プロジェクトに㧍ける研究課題「常緑広葉樹林 に扔ける斜面水文プロセスの解明 - 針葉樹林・竹林と比較して斜面崩 壊は起こりやすいのか? 一」を用いて行われました。小松 光特定准 教授（京都大学白眉センター）と普段から行っている森林管理に関す る議論は, 本原稿の作成に大変役立ちました。匿名査読者 2 名の方と 担当編集委員の方には，原稿を丁寧にご確認いただき，有意義で示唆 に富んだご意見をいただきました。ここに記して感謝の意を表します。

\section{引用文献}

Adelman JD, Ewers BE, Mackay DS (2008) Use of temporal patterns in vapor pressure deficit to explain spatial autocorrelation dynamics in tree transpiration. Tree Physiol 28: 647-658

Asbjornsen H, Goldsmith GR, Alvarado-Barrientos MS, Rebel K, Van Osch FP, Rietkerk M, Chen J, Gotsch S, Tobón C, Geissert DR, GómezTagle A, Vache K, Dawson TE (2011) Ecohydrologal advances and applications in plant-water relations research: a review. J Plant Ecol 4: 3-22 
Bréda N, Granier A, Aussenac AC (1995) Effects of thinning on soil and tree water relations, transpiration and growth in an oak forest (Quercus petraea (Matt.) Liebl.). Tree Physiol 15: 295-306

Burgess SSO, Adams MA, Turner NC, Beverly CR, Ong CK, Khan AAH, Bleby TM (2001) An improved heat pulse method to measure low and reverse rates of sap flow in woody plants. Tree Physiol 21: 589-598

Bush S, Hultine KR, Sperry JS, Ehleringer JR (2010) Calibration of thermal dissipation sap flow probes for ring- and diffuse-porous trees. Tree Physiol 30: 1545-1554

Čermák J, Kučera J, Nadezhdina N (2004) Sap flow measurements with some thermodynamic methods, flow integration within trees and scaling up from sample trees to entire forest stands. Trees 18: 529-546

Čermák J, Kučera J, Bauerle WL, Phillips N, Hinckley TM (2007) Tree water storage and its diurnal dynamics related to sap flow and changes in stem volume in old-growth Douglas-fir trees. Tree Physiol 27: 181198

Chang X, Zhao W, Zhang Z, Su Y (2006) Sap flow and tree conductance of shelter-belt in arid region of China. Agric For Meteorol 138: 132-141

Clearwater MJ, Meinzer FC, Andrade JL, Goldstein G, Holbrook M (1999) Potential errors in measurement of nonuniform sap flow using heat dissipation probes. Tree Physiol 19: 681-687

Closs RH (1958) The heart plus method for measuring rate of sap flow in a plant stem. NZ J Sci 1: 281-288

Daikoku K, Hattori S, Deguchi A, Aoki Y, Miyashita M, Matsumoto K, Akiyama J, Iida S, Toba T, Fujita Y, Ohta T (2008) Influence of evaporation from the forest floor on evapotranspiration from the dry canopy. Hydrol Process 22: 4083-4096

Delzon S, Sartore M, Granier A, Loustau, D (2004) Radial profiles of sap flow with increasing tree size in maritime pine. Tree Physiol 24: 12851293

Delson S, Loustau D (2005) Age-related decline in stand water use: sap flow and transpiration in a pine forest chronosequence. Agric For Meteorol 129: 105-119.

Dung BX, Gomi T, Miyata S, Sidle RC, Kosugi K, Onda Y (2012) Runoff responses to forest thinning at plot and catchment scales in a headwater catchment draining Japanese cypress forest. J Hydrol 444445: 51-62

Farley KA, Jobbagy EG, Jackson RB (2005) Effects of afforestation on water yield: a global synthesis with implications for policy. Global Change Biol 11: 1565-1576

Flora A, Cescatti A (2006) Diurnal and seasonal variability in radial distribution of sap flux density: implications for estimating stand transpiration. Tree Physiol 26: 1217-1225

Flora A, Cescatti A (2008) Vertical foliage distribution determines the radial pattern of sap flux density in Picea abies. Tree Physiol 28: 1317-1323

Ford CR, Goranson CE, Mitchell RJ, Will RE, Teskey RO (2004) Diurnal and seasonal variability in the radial distribution of sap flow: predicting total stem flow in Pinus taeda trees. Tree Physiol 24: 951-960

Ford CR, Hubbard RM, Kloeppel BD, Vose JM (2007) A comparison of sap fluxbased evapotranspiration estimates with catchment-scale water balance. Agric For Meteorol 145: 176-185

Forrester DI, Collopy JJ, Beadle CL, Warren CR, Baker TG (2012) Effect of thinning, pruning and nitrogen fertilizer application on transpiration, photosynthesis and water-use efficiency in a young Eucalyptus nitens plantation. For Ecol Manage 266: 286-300

藤山洋介・廣瀬茂樹・大槻恭一・小川 滋（2005）Granier 法による樹 液流測定に基づくヒノキ林における蒸散量の推定一御手洗水試験 流域における観測例一。 九大演報 86: 15-31

Gebauer T, Horna V, Leuschner C (2008) Variability in radial sap flux density patterns and sapwood area among seven co-occurring temperate broad-leaved tree species. Tree Physiol 28: 1821-1830

Granier A (1985) A new method of sap flow measurement in tree stems. Annales Des Sciences Forestières 43: 193-200

Granier A (1987) Evaluation of transpiration in a Douglas-fir stand by means of sap flow measurements. Tree Physiol 3: 309-320

Granier A, Biron P, Bréda N, Pontailler JY, Saugier B (1996a) Transpiration of trees and forest stands: short and long-term monitoring using sapflow methods. Global Change Biol 2: 265-274

Granier A, Biron P, Köstner B, Gay LW, Najjar G. (1996b) Comparisons of xylem sap flow and water vapour flux at the stand level and derivation of canopy conductance for Scots pine. Theor Appl Climatol 53: 115122

Granier A, Biron P, Lemoine D (2000) Water balance, transpiration and canopy conductance in two beech stands. Agric For Met 100: 291-208

芳賀弘和・大槻恭一 - 小川 滋 (2002) 広島県江田島流域での山火事後 約 20 年後における基底流出の変化. 水水学会誌 15: 584-593

Hatton TJ, Moore SJ, Reece PH (1995) Estimating stand transpiration in a Eucalyptus populnea woodland with the heat pulse method: measurement errors and sampling strategies. Tree Physiol 15: 219-227

Herbst M, Roberts JM, Rosier PTW, Taylor ME, Gowing DJ (2007) Edge effects and forest water use: A field study in a mixed deciduous woodland. For Ecol Manage 250: 176-186

Herbst M, Rosier PTW, Morecroft MD, Gowing DJ (2008) Comparative measurements of transpiration and canopy conductance in two mixed deciduous woodlands differing in structure and species composition. Tree Physiol 28: 959-970

Herzog KM, Thum R, Zweifel R, Hasler R (1997) Heat balance measurements: To quantify sap flow in thin stems only? Agric For Meteorol 83: 75-94

Hirano T, Hirata R, Fujinuma Y, Saigusa N, Yamamoto S, Harazono Y, Takada M, Inukai K, Inoue G (2003) $\mathrm{CO}_{2}$ and water vapor exchange of a larch forest in northern Japan. Tellus 55: 244-257

Hirose S, Kume A, Takeuchi S, Utsumi Y, Otsuki K, Ogawa S (2005) Stem water transport of Lithocarpus edulis, an evergreen oak with radialporous wood. Tree Physiol 25: 221-228

飯田真一・中谷 壮・田中 正 (2006) 山地源流域の落葉広葉樹林にお ける樹液流速測定に基づく林分蒸散量の評価. 水水学会誌 19: 7-16

Iida S, Tanaka T, Sugita M (2006) Change of evapotranspiration components due to the succession from Japanese red pine to evergreen oak. J Hydrol 326: 166-180

Iida S, Ohta T, Matsumoto K, Nakai T, Kuwada T, Kononov A, Maximov T, van der Molen MK, Dolman H, Yabuki H (2009) Evapotranspiration from understory vegetation in an eastern Siberian boreal larch forest. Agric For Meteorol 149: 1129-1139

今若慎太郎・佐藤宣子 (2008)「森林環境税」による新たな森林整備に関 する研究 .九大演報 89: 75-126

James SA, Clearwater MJ, Meinzer FC, Goldstein G (2002) Heat dissipation sensors of variable length for the measurement of sap flow in trees with deep sapwood. Tree Physiol 22: 277-283

Jiménez MS, Nadezhdina N, Čermák J, Morales D (2000) Radial variation in sap flow in five laurel forest tree species in Tenerife, Canary Islands. Tree Physiol 20: 1149-1156

梶原幹弘 (1973) 相対幹曲線と関連しての樹皮幹厚率について。日林誌 55: $132-139$

梶原幹弘 (1985) スギ同齢林における樹皮厚率とその推定について. 京 都府大学報 37: 189-194

Katsuyama M, Fukushima K, Tokuchi N (2008) Comparison of rainfallrunoff characteristics in forested catchments underlain by granitic and sedimentary rock with various forest age. Hydrol Res Lett 2: 14-17

Kelliher FM, Leuning R, Raupach MR, Schulze ED (1995) Maximum conductances for evapoeration from global vegetation types. Agric For Meteorol 73: 1-16

小林 剛・多田壮宏 (2010) モウソウチクは里山林の炭素吸収・貯蔵お よび有機物分解にどのような影響をもたらしうるか? 森林科学 58: 6-10

Kobayashi Y, Tanaka T (2001) Water flow and hydraulic characteristics of Japanese red pine and oak trees. Hydrol Process 15: 1731-1750

小谷二郎・江崎功二郎 (2012) 放置期間の違いが竹林の下層植生の発達 に与える影響. 森林立地 $54: 19-28$

Komatsu H (2005) Forest categorization according to dry-canopy evaporation rates in a growing season: Comparison of the PriestleyTaylor coefficient values from various observation sites. Hydrol Process 19: 3873-3896

小松 光・堀田紀文 (2005) 森林蒸発散フラックス計測大流行の産物. 
水水学会誌 18: 613-626

小松 光・澤野真治 - 久米朋宣 - 橋本昌司 (2005) 森林の特性と蒸発散 量の関係. 日林誌 87: 170-185

小松 光 (2007) 日本の針葉樹人工林における立木密度と遮断率の関 係. 日林誌 89: 217-220

Komatsu H, Tanaka N, Kume T (2007) Do coniferous forests evaporate more water than broad-leaved forest in Japan? J Hydrol 336: 361-375

Komatsu H, Kume T, Otsuki K. (2008) The effect of converting a native broad-leaved forest to a coniferous plantation forest on annual water yield: a paired-catchment study in northern Japan. For Ecol Manage 255: 880-886

小松 光 ・ 久米朋宣 - 大槻恭一 (2009) 針葉樹人工林の間伐が年遮断蒸 発散量に与える影響—予測モデルの検証一。 日林誌 91: 94-103

小松 光 (2010) 森林と水資源. 水利科学 314: 1-29

Komatsu H, Kume T, Shinohara Y, Miyazawa Y, Otsuki K (2010a) Did annual runoff and low flow decrease with reduced forestry practices in Japan? Hydrol Process 24: 2440-2451

Komatsu H, Onozawa Y, Kume T, Tsuruta K, Kumagai T, Shinohara Y, Otsuki K (2010b) Stand-scale transpiration estimates in a Moso bamboo forest: (II) Comparison with coniferous forests. For Ecol Manage 260: 1295-1302

Komatsu H, Onozawa Y, Kume T, Tsuruta K, Shinohara Y, Otsuki K (2012) Canopy conductance for a Moso bamboo (Phyllostachys pubescens) forest in western Japan. Agric For Meteorol 156: 111-120

Kosugi Y, Takanashi S, Tanaka H, Ohkubo S, Tani M, Yano M, Katayama T (2007) Evapotranspiration over a Japanese cypress forest. I. Eddy covariance fluxes and surface conductance characteristics for 3 years. J Hydrol 337: 269-283

Kubota M, Tenhunen J, Zimmermann R, Schmidt M, Adiku S, Kakubari Y (2005a) Influences of environmental factors on the radial profile of sap flux density in Fagus crenata growing at different elevations in the Naeba Mountains, Japan. Tree Physiol 25: 545-556.

Kubota M, Tenhunen J, Zimmermann R, Schmidt M, Kakubari, Y (2005b) Influence of environmental conditions on radial patterns of sap flux density of a 70-year Fagus crenata trees in the Naeba Mountains, Japan. Ann For Sci 62: 289-296

熊谷朝臣 (2007) 幹の中を流れる水から森林の蒸散を考える.（森林水文 学. 森林水文学編集委員会編, 森北出版). 110-130

Kumagai T, Aoki S, Nagasawa H, Mabuchi T, Kubota K, Inoue S, Utsumi Y, Otsuki K (2005a) Effects of tree-to-tree and radial variations on sap flow estimates of transpiration in Japanese cedar. Agric For Meteorol 135: $110-116$

Kumagai T, Nagasawa H, Mabuchi T, Ohsaki S, Kubota K, Kogi K, Utsumi Y, Koga S, Otsuki K (2005b) Sources of error in estimating stand transpiration using allometric relationships between stem diameter and sapwood area for Cryptomeria japonica and Chamaecyparis obtusa. For Ecol Manage 206: 191-195

Kumagai T, Aoki S, Shimizu T, Otsuki K (2007) Sap flow estimates of stand transpiration at two slope positions in a Japanese cedar forest watershed. Tree Physiol 27: 161-168

Kumagai T, Tateishi M, Shimizu T, Otsuki K (2008) Transpiration and canopy conductance at two slope positions in a Japanese cedar forest watershed. Agric For Meteorol 148: 1444-1455

Kumagai T, Aoki S, Otsuki K, Utsumi Y (2009) Impact of stem water storage on diurnal estimates of whole-tree transpiration and canopy conductance from sap flow measurements in Japanese cedar and Japanese cypress trees. Hydrol Process 23: 2335-2344

Kume T, Onozawa Y, Komatsu H, Tsuruta K, Shinohara Y, Umebayashi T, Otsuki K (2010a) Stand-scale transpiration estimates in a Moso bamboo forest: (I) Applicability of sap flux measurements. For Ecol Manage 260: 1287-1294

Kume T, Tsuruta K, Komatsu H, Kumagai T, Higashi N, Shinohara Y, Otsuki K (2010b) Effects of sample size on sap flux-based stand-scale transpiration estimates. Tree Physiol 30: 129-138

Kume T, Otsuki K, Du S, Yamanaka N, Wang YL, Liu GB (2012a) Spatial variation in sap flow velocity in semiarid region trees: its impact on stand-scale transpiration estimates. Hydrol Processes 26: 1161-1168
Kume T, Tsuruta K, Komatsu H, Shinohara Y, Katayama A, Ide J, Otsuki K (2012b) Scaling transpiration from stand to a watershed in a Japanese Cypress plantation. 3rd International Conference on Forest \& Water in a Changing Environment. 54

蔵治光一郎・芝野博文 (2001) 大学演習林試験流域における水文観測. 水水学会誌 14: 489-498

蔵治光一郎 (2012) 森の「恵み」は幻想か 科学者が考える森と人の関 係, 化学同人

藏本康平・篠原慶規・小松 光・大槻恭一 (2010) 森林回復が流出に及 ぼす影響一地質の異なる 2 流域に打ける検討一. 水水学会誌 23 : $32-42$

Kuroda K, Yamashita K, Fujiwara T (2009) Cellular level observation of water loss and the refilling of tracheids in the xylem of Cryptomeria japonica during heartwood formation. Trees 23: 1163-1172

黒鳥四朗（1954）スギの所謂白線帶についての研究（第 1 報）。日林誌 36: $15-19$

Lagergren F, Lankreijer H, Kučera J, Cienciala E, Molder M, Lindroth A (2008) Thinning effects on pine-spruce forest transpiration in central Sweden. For Ecol Manage 255: 2312-2323

López-Bernal Á, Alcantára S, Testi L, Villalobos FJ (2010) Spatial sap flow xylem anatomical characteristics in olive trees under different irrigation regimes. Tree Physiol 30: 1536-1544.

Loranty MM, Mackay DS, Ewers BE, Adelman JD, Kruger EL (2008) Environmental drivers of spatial variation in whole-tree transpiration in an aspen-dominated upland-towetland forest gradient. Water Resour Res 44: W02441.

Lu P, Müller WJ, Chacko EK (2000) Spatial variations in xylem sap flux density in the trunk of orchard-grown, mature mango trees under changing soil water conditions. Tree Physiol 20: 683-692

Lu P, Urban L, Ping Z (2004) Granier's themal dissipation probe (TDP) method for measuring sap flow in trees: Theory and practice. Acta Bot Sinica 46: 631-646

Mackay DS, Ewers BE, Loranty MM, Kruger EL (2010) On the representativeness of plot size and location for scaling transpiration from trees to a stand. J Geophys Res 115: G02016

MacKay SL, Arain MA, Khomik M, Brodeur JJ, Schumacher J, Hartmann H, Peichl M (2012) The impact of induced drought on transpiration and growth in a temperate pine plantation forest. Hydrol Process 26: 1779-1791

真板英一・鈴木雅一 (2007) 千葉袋山沢流域における伐採による月流出 量変化. 日林誌 $89: 278-287$

真板英一・鈴木雅一 (2008) 森林植生の伐採が山地小流域の流況曲線に 与える影響一流況の流域間変動に対する植生要因の大きさの検 討一. 日林誌 90: 36-45

丸山利輔・中島史雄・勝山達郎・有川光造 (2009) いしかわ森林環境 税, 森林整備と過疎地の雇用創出. 農業農村工誌 77: 353-357

Matsumoto K, Ohta T, Nakai T, Kuwada T, Daikoku K, lida S, Yabuki H, Kononov AV, van der Molen MK, Kodama Y, Maximov TC, Dolman AJ, Hattori S (2008a) Responses of surface conductance to forest environments in the Far East. Agric For Meteorol 148: 1926-1940

Matsumoto K, Ohta T, Nakai T, Kuwada T, Daikoku K, Iida S, Yabuki H, Kononov AV, van der Molen MK, Kodama Y, Maximov TC, Dolman AJ, Hattori S (2008b) Energy consumption and evapotranspiration at several boreal and temperate forests in the Far East. Agric For Meteorol 148: 1978-1989

Matsumura J, Yamasaki Y, Oda K, Fujisawa Y (2005) Profile of bordered pit aspiration in Cryptomeria japonica using confocal laser scanning microscopy: pit aspiration and heartwood color. J Wood Sci 51: 328 333

Meinzer FC, Goldstein G, Andrade JL (2001) Regulation of water flux through tropical forest canopy trees: Do universal rules apply? Tree Physiol 21:19-26

Mizutani K, Yamanoi K, Ikeda T, Watanabe T (1997) Applicability of the eddy correlation method to measure sensible heat transfer to forest under rainfall conditions. Agric For Meteorol 86: 193-203

Miyazawa Y, Tateishi M, Komatsu H, Kumagai T, Otsuki K (2011) Are measurements from excised leaves suitable for modeling diurnal 
patterns of gas exchange of intact leaves? Hydrol Process 25: 29242930

Moore GW, Bond BJ, Jones JA, Meinzer FC (2010) Thermal-dissipation sap flow sensors may not yield constant sap-flux estimates over multiple years. Trees 24 : $165-174$

森川 靖 (1974) ヒノキの樹液の流れ一林木の水分収支と関連して一. 東大演報 66: 251-297

Morikawa Y, Hattori S, Kiyono Y (1986) Transpiration of a 31-year-old Chamaecyparis obtusa Endl. stand before and after thinning. Tree Physiol 2: 105-114

虫明功臣・高橋 裕・安藤義久 (1981) 日本の山地河川の流況に及ぼす 流域の地質の効果. 土木学会論報 309: 51-62

南光一樹 - 恩田裕一 - 深田佳作 - 野々田稔郎 - 山本一清 - 竹中千里 平岡真合乃 (2010) 荒廃ヒノキ人工林の強度間伐が森林水源涵養 機能に与える経済効果の試算. 水水学会誌 23: 437-443

日本学術会議 (2001) 地球環境・人間生活にかかわる農業及び森林の多 面的な機能の評価について (答申).

新山 馨・ 小川みふゆ・九島宏道・高橋和規 - 佐藤 保 - 酒井 武 田内裕之（2010）人工林の広葉樹林化に向けた広葉樹の更新に関 する文献の収集と評価. 日林誌 92: 292-296

西川僚子・村上拓彦・吉田茂二郎・光田 靖 - 長島啓子 - 溝上展也 （2005）隣接する土地被覆別にみた竹林分布変化の特徵. 日林誌 87 : 402-409

恩田裕一 (2008) 人工林荒廃と水・土砂流出の実態. 岩波書店

Onozawa Y, Chiwa M, Komatsu H, Otsuki K (2009) Rainfall interception in a moso-bamboo (Phyllostachys pubescens) forest. J For Res 14: 111116.

小野澤郁佳 - 久米朋宣 - 小松 光 - 鶴田健二 - 大槻恭一 (2009) 樹液流 計測のモウソウチクへの適用一切り竹における吸水量と樹液流量 の比較一. 日林誌 91: 366-37

Oren R, Phillips N, Katul G, Ewers BE, Pataki DE (1998) Scaling xylem sap flux and soil water balance and calculating variance: a method for partitioning water flux in forests. Ann Sci For 55:191-216

Oren R, Phillips N, Ewers BE, Pataki DE, Megonigal JP (1999) Sap-fluxscaled transpiration responses to light, vapor pressure deficit, and leaf area reduction in a flooded Taxodium distichum forest. Tree Physiol 19: $337-347$

Pataki DE, Oren R (2003) Species differences in stomatal control of water loss at the canopy scale in a mature bottomland deciduous forest. Adv Water Resour 26: 1267-1278

Phillips N, Oren R, Zimmermann R (1996) Radial patterns of xylem sap flow in non-, diffuse-, and ring-porous tree species. Plant Cell Environ 19: $983-990$

Phillips N, Nagchaudhuri A, Oren R, Katul G (1997) Time constant for water transport in loblolly pine trees estimated from time series of evaporative demand and stem sapflow. Trees 11: 412-419

林野庁 (2012) 平成 23 年度森林・林業白書

Roberts S, Vertessy R, Grayson R (2001) Transpiration from Eucalyptus sieberi (L. Johnson) forests of different age. For Ecol Manage 143: 153-161

斎藤 环 (2009) 微気象学的な測定 (渦相関法による測定). 低温科学 67: $129-136$

作田耕太郎・玉泉幸一郎・矢幡 久 (1992) 茎熱収支法によるヒノキ成 木の樹液流量の測定と樹体に扮ける通水抵抗. 九大演報 65: 895106

Sakuratani T (1984) Improvement of the Probe for Measuring Water Flow Rate in Intact Plants with the Stem Heat Balance Method. J Agric Meteorol 40: 273-277

佐藤貴紀・田中延亮・井上 淳 - 澤田晴雄 - 渡部 賢・鈴木雅一 （2010）愛知演習林のコナラを対象にした樹液流の染色実験の報 告. 演習林 49: 29-41

志水俊夫 (1980) 山地流域における渇水量と表層地質・傾斜・植生との 関係. 林試研報 310: 109-128

Shinohara Y, Kumagai T, Otsuki K, Kume A, Wada N (2009) Impact of climate change on runoff from a mid-latitude mountainous catchment in central Japan. Hydrol Process 23: 1418-1429

篠原慶規・井手淳一郎・東 直子・小松 光 - 久米朋宣 - 智和正明 -
大柣恭一（2010）管理放棄されたヒノキ人工林における樹冠遮断 量の計測. 日林誌 92: 54-59

Shinohara Y, Komatsu H, Kuramoto K, Otsuki K (2013a) Characteristics of canopy interception loss in Moso bamboo forests of Japan. Hydrol Process 27: 2041-2047

Shinohara Y, Tsuruta K, Ogura A, Noto F, Komatsu H, Otsuki K, Maruyama $\mathrm{T}$ (2013b) Azimuthal and radial variations in sap flux density and effects on stand-scale transpiration estimates in a Japanese cedar forest. Tree Physiol 33: 550-558

Simonin K, Kolb TE, Montes-Helu M, Koch GW (2007) The influence of thinning on components of stand water balance in a ponderosa pine forest stand during and after extreme drought. Agric For Meteorol 143: 266-276

Smith DM, Allen SJ (1996) Measurement of sap flow in plant stems. J Exp Bot 47: 1833-1844

Steppe K, De Pauw DJW, Doody T, Teskey RO (2010) A comparison of sap flow density using thermal dissipation, heat pulse velocity and heat field deformation methods. Agric For Meteorol 150: 1046-1056

Swanson RH (1994) Significant historical developments in thermal methods for measuring sap flow in trees. Agric For Meteorol 72: 113132

Swanson RH, Whitefield DWA (1981) A numerical analysis of heat plus velocity theory and practice. J Exp Bot 32: 221-239

玉井幸治・後藤義明・深山貴文・小南裕志 (2004) 林野火災とマツ枯れ による森林の衰退が流出量と流況曲線に及ぼす影響一岡山市竜の 口山量水試験地の場合一。 日林誌 86: 375-379

玉井幸治・清水 晃・細田育広・宮縁育夫 ・清水貴範 - 深山貴文 - 小 南裕志・浅野志穂 (2008) 様々な森林攪乱が流況曲線に及ぼす影 響一宮崎市「去川森林理水試験地」と岡山市「竜ノ口山森林理水 試験地」の事例比較一. 森林総研研報 7:111-120

Tanaka T, Uchida E, Siaw OA, Takeda Y, Tomatsu O (1993) Effect of the lag time of sap temperature on sap-flow measurements using the heatbalance method. J Jpn For Soc 75: 554-557

Tanaka T, Uchida E, Yokota T, Hagihara A, Takeda Y (1994) Comparison between water absorption rate and sap-flow rate measured using the improved stem heat-balance method. J Jpn For Soc 76: 500-505

田中隆文 (1996) 蒸発散の測定法（2). ハイドロロジー 26: 135-143

丹下 健 (1987) 19 年生スギ人工林の斜面上部, 中部, 下部における年 蒸散量の推定. 東大演報 76: 177-196

Tateishi M, Kumagai T, Utsumi Y, Umebayashi T, Shiiba Y, Inoue K, Kaji K, Cho K, Otsuki K (2008) Spatial variations in xylem sap flux density in evergreen oak trees with radial-porous wood: comparisons with anatomical observations. Trees 23: 23-30

Tateishi M, Kumagai T, Suyama Y, Hiura T (2010) Differences in transpiration characteristics of Japanese beech trees, Fagus crenata, in Japan. Tree Physiol 30: 748-760

豊田信行・得居 輝・松岡真悟 (2005) モウソウチクの林分構造と混交 による樹木の成長変化. 愛知県林研技報 23: 29-34

鶴田建二 (2011) 単木スケールの樹液流計測を用いたヒノキ人工林の蒸 散量の推定. 九州大学博士論文.

Tsuruta K, Kume T, Komatsu H, Higashi N, Umebayashi T, Kumagai T, Otsuki K (2010) Azimuthal variations of sap flux density within Japanese cypress xylem trunks and their effects on tree transpiration estimates. J For Res 15: 398-403

鶴田健二 - 小松 光 - 篠原慶規 - 久米朋宣・市橋隆自・大柣恭一 （2011）樹液流計測に基づいたスギとヒノキの林分蒸散量算定のた めの辺材面積推定式. 水水学会誌 24: 261-270

Umebayashi T, Utsumi Y, Koga S, Inoue S, Fujikawa S, Arakawa K, Matsumura J, Oda K (2008) Xylem water conducting pathways of deciduous broadleaved trees growing in a northern temperate zone. IAWA J 29: 247-263

和口美明 (2003) 奈良県におけるヒノキ同齢林の樹皮厚率. 奈良県森林 技セ研報 32: 1-6

Vertessy RA, Hatton TJ, Reece P, O'Sullivan SK, Benyon RG (1997) Estimating stand water use of large mountain ash trees and validation of the sap flow measurement technique. Tree Physiol 17: 747-756

Vertessy RA, Watson FGR, O'Sullivan SK (2001) Factors determining 
relations between stand age and catchment water balance in mountain ash forests. For Ecol Manage 143: 13-26

Wang YL, Liu GB, Kume T, Otsuki K, Yamanaka N, Du A (2010) Estimating water use of a black locust plantation by the thermal dissipation probe method in the semiarid region of Loess Plateau, China. J For Res 15: 241-251

Wilson KB, Hanson PJ, Mulholland PJ, Baldocchi DD, Wullschleger SD (2001) A comparison of methods for determining forest evapotranspiration and its components: sap-flow, soil water budget, eddy covariance and catchment water balance. Agric For Meteorol 106: 153-168

Wullschleger SD, Meinzer FC, Vertessy RA (1998) A review of whole-plant water use studies in trees. Tree Physiol 18: 499-512
Wullschleger SD, Childs KW, King AW, Hanson PJ (2011) A model of heat transfer in sapwood and implications for sap flux density measurements using thermal dissipation probes. Tree Physiol 31: 669-679

Xue B, Kumagai T, lida S, Nakai T, Matsumoto K, Komatsu H, Otsuki K, Ohta T (2011) Influences of canopy structure and physiological traits on flux partitioning between understory and overstory in an eastern Siberian boreal larch forest. Ecol Model 222: 1479-1490

横尾謙一郎・酒井正治・今矢明宏 (2005) ヒノキ人工林に侵入した竹が 林分構造と土袞に与える影響. 九州森林研究 58: 195-198

山本哲也・池田作太郎 (2005) 水土保全機能強化総合モデル事業地にお ける森林の変遷と流出特性一水源涵養機能を向上させる森林整備 の方向性一. 広島県林技七研報 37: 15-33 